Değini

Türkiye'de iletişim Araștırmaları iç̧inde 1970'li Yıllarda Ankara Üniversitesi

Siyasal Bilgiler Fakültesinde Yapılan iletişim Konusundaki

Doktora Tezlerinin Rolü ve Konumu"

\title{
Oya Tokgöz
}

Ankara Üniversitesi iletişim Fakültesi

(Emekli) Öğretim Üyesi

\section{Türkiye'de iletișim araștırmalarının gelișim çizgisi}

Türkiye'de iletişim araştırmalarının XX. yüzyılın ilk çeyreğinden başlayarak yapılmakta olduğunu söylemek yanlış olmaz. İletişim araştırması olarak değerlendirilebilecek ve nitelenebilecek olan ilk çalışma, 1914 yılında ABD'de Columbia Üniversitesi'ne Ahmet Emin Yalman tarafından sunulan basın tarihi çalışmasıdır. Bu çalışmanın XX. yüzyılın başında Osmanlı Devleti'ndeki basın/iktidar ilişkilerini değerlendiren bir çalışma olarak tarihi rolü ve önemi bulunmaktadır.

İletişimi konu alan çalışmaların XX. yüzyılın içinde ilerleyen yıllarda yapılmış olduğunu görebilmek mümkündür. Bu çalışmaları, edebiyatçılar, siyaset bilimciler, sosyal psikologlar, sosyologlar, eğitimciler yapmışlardır. Tarihçi ve edebiyatçılar, gazete ve gazetecileri incelerlerken, sosyologlar, siyaset bilimciler, eğitimciler, sosyal psikologlar izledikleri konuya yardımcı olma-

* Daha önce İletişim Ve (A. Aziz ve S. Sungur, der.) isimli kitapta yer alan bu yazı, yazarın izniyle yayınlanmiştır.

http://ilefdergisi.org/2014/1/1/

ilef dergisi · ilef journal • ( $2014 \cdot 1(1) \cdot$ bahar/spring: 115-142 
Sı nedeniyle kitle iletişim araçlarını değerlendirmeyi uygun görmektedirler. Bu gibi çalışmaların daha çok İstanbul Üniversitesi Edebiyat Fakültesi ile Cumhuriyetin ilk üniversitesi olan Ankara Üniversitesi Dil Tarih ve Coğrafya Fakültesi'nde yapılmış olmaları dikkat çekicidir. Özellikle, bu gibi çalışmaların Türkiye'de sosyal bilimlerin ve sosyal bilim çalışması yapma geleneğinin gelişmemiş olduğu yıllarda yapılmış olmaları gerçekten önemlidir.

1950'li ve 1960'lı yıllarda ise, iletişim araştırmaları bakımından önceki yıllara göre durumun biraz farklılık gösterdiğini söyleyebiliriz. Devlet Planlama Teşkilatı ile Ankara Üniversitesi Siyasal Bilgiler Fakültesi'nde yapılmış bulunan araştırmalar öne çıkmaktadır. Aynı yıllar içinde, ABD'de modernleşme yaklaşımları kullanılarak bazı araştırmalar yapılmaktadır. Ne olursa olsun, 1950'li y1llarla birlikte başlayan hareketlenme ve canlanma, Türkiye' de gerek kültürel alanda gerekse siyasal alanda bazı değişiklikleri birlikte getirmiştir. Bu değişiklikler, aynı zamanda Türk siyasal ve kültürel yaşamı bakımından önemli kırılma noktalarını da oluşturmuştur.

\section{Türkiye'de toplumsal yașamın farklılașması ve zenginleșmesine neden olan koșullar}

1945 yılında II. Dünya Savaşı bittikten sonra, Türkiye'de çok partili yaşama geçmek için çeşitli girişimler yapıldığını söylemek yanlış olmaz. Bu girişimlerin en önemlisi ise, Cumhuriyet Halk Partisi içinden ayrılan bir grupça Demokrat Parti'nin kurulmasıdır. Demokrat Parti 1946'da yapılan genel seçime katılmıs, 1950 yılında da iktidara gelmiştir. Cumhuriyetin kuruluşundan itibaren iktidarda bulunan CHP'den sonra DP'nin iktidara gelmesi, Türk siyasal yaşamı ve siyasal kültüründe hiç kuşkusuz değişikliklerin görülmesine neden olmuştur. Çok partili siyasal yaşama geçilmiştir.

\section{Gazetecilikle görülen değișiklikler}

1948 yılında Sedat Simavi tarafından kurulan Hürriyet gazetesi bir haber gazetesi olarak Bab-1 Ali' de yayın yaşamına girmiştir. Ali Naci Karacan tarafından kurulan Milliyet gazetesi 1950'de yayına başlamıştır. Her iki gazetenin yaptığı habercilik Bab-ı Ali'de hem çok ses getirmiş hem de çok yadırganmıştrr. Bu gazeteler aleyhine kampanyalar başlatılsa bile, getirilen yeni habercilik anlayışı ile yılmadan çalışmalarını sürdürmeye devam etmiştir.

1950'de yeni Basın Yasası yürürlüğe girmiştir. Bu yasa Demokrat Parti tarafından çıarılan bir yasa olarak basın cezalarında daha uygar hükümler 
taşımaktadır. Bununla birlikte, özgür hükümler taşıdığı ileri sürülen yasanın ömrü uzun sürmemiştir. 1950'li yıllar içinde pek çok değişikliğe uğramıştır. Yasanın özgür sayılan bazı hükümleri değiştirilmiş, önemli kısıtlamalar getirilmiştir. Devlet tekeli altında yayın yapan radyo ise, DP tarafından 1950'li yılların sonuna doğru partizanca kullanılmıştır.

\section{1 anayasasının yürürlüğe girmesi}

27 Mayıs 1960'da yapılan ilk askeri darbeden sonra, DP'nin on y1l süren iktidarı sona ermiştir. 1961 yılında Kurucu Meclis tarafından yapılan 1961 Anayasası yürürlüğe girmiştir. Bir tepki anayasası olarak nitelenen bu anayasa, Cumhuriyetin ilk anayasası olan 1924 Anayasasını değiştirerek, bireysel haklar ve özgürlükler bakımından daha ileri ve uygar hükümler getirmiştir. Ayrıca, bu anayasa ile birlikte bazı yeni anayasal kurumlar kurulmuştur. Bu kurumlar arasında Devlet Planlama Teşkilatı, Anayasa Mahkemesi ve Türkiye Radyo ve Televizyon Kurumu'nun adlarını saymak gerekir.

Devlet Planlama Teşkilatı'nın kurulmasıyla birlikte, beş yıllık kalkınma planları yapılarak planlı ekonomi dönemi başlamıştır. Anayasa Mahkemesi'nin kurulması ise Türkiye Büyük Millet Meclisi tarafından çıkarılan yasaların yasallığının tartışılması açısından önemli bir adım oluşturmuştur. TRT'nin kuruluşu ise, zamanın koşulları bakımından bir devrim niteliğindedir denilebilir. İngiliz yayın kuruluşu BBC gibi özerk bir kamu kuruluşu olarak TRT’nin 1964 yılı başında kurulması, toplumda çok yadırganmıştır.

İşin ilginç tarafı TRT kurulduğu zaman, Türkiye' de birkaç kentte radyo vericisi bulunmaktadır fakat radyo vericilerinin teknolojisi çok eskidir. Radyo yayınları Türkiye'nin tümünü kapsamadığı gibi, radyo yayıncılığı fazla gelişmemiş durumdadır. Televizyon yayını ve alıcıları ise Türkiye'de hemen hemen hiç bulunmamaktadır.

\section{Türkiye'de gazetecilik/iletișim eğitiminin bașlaması}

1950 yılında İstanbul Gazeteciler Cemiyetinin, İstanbul Gazeteciler Sendikasının eğitimli gazeteci yetiştirilmesi yönünde istekte bulunmaları, İstanbul Üniversitesi İktisat Fakültesi içinde Gazetecilik Enstitüsü'nün kurulmasıyla sonuçlanmıştır. Aynı yıl içinde Gazetecilik Enstitüsü üç yıllık gazetecilik eğitimi vermek üzere, kapılarını öğrencilere açmıştır. Bu eğitim çalışmaları yıllar içinde aksayarak da olsa devam etmiştir. 
Türkiye'de bu yönde ikinci girişim, Ankara Gazeteciler Cemiyeti, Gazeteciler Sendikası, Anadolu Ajansı tarafından yapılmıştır. Yapılan istek, eğitimli, dil bilen gazetecilerin yetiştirilmesi yönündedir. Gazetecilik kuruluşları tarafından yapılan girişimleri Ankara Üniversitesi Siyasal Bilgiler Fakültesi'nin kabul etmesi üzerine, UNESCO'nun desteği sağlanarak, 1964 yılında AÜ SBF Basın Yayın Yüksek Okulu kurulmuştur. Okul, İstanbul'daki Gazetecilik Enstitüsü'nün aksine, kitle iletişim araçları üzerine dört yıl eğitim verecek bir okul olarak kurularak, öğrencilerine 1964-1965 ders yılında kapılarını açmıştır.

AÜ SBF BYYO'nun programları gazetecilik, halkla ilişkiler ve radyotelevizyon programları olarak düzenlenmiştir. Bu programlara uygun şekilde öğrenci alınmış fakat halkla ilişkiler programı bakımından ilk yıl içinde okutulacak ders ve dersleri okutacak öğretim üyesi bulunmasının zorluğu nedeniyle, gazetecilik ve halkla ilişkiler programları birleştirilmiştir. Okul ilk mezunlarını 1969' da vermiştir.

Bu iki eğitim kurumu yanında 1967 yılından itibaren, Ankara, İstanbul ve İzmir'de 1961 Anayasasının ilgili maddelerinden yararlanılarak, özel basın yayın yüksek okulları açılmaya başlanmıştır. 1970 yılında her üç özel yüksek okul devletleştirilerek, iktisadi ve ticari ilimler akademilerine bağlanmışlardır. Sayısı 5 olan Basın Yayın Yüksek Okulu 1982'den sonra İstanbul, Ankara, Gazi, Marmara, Ege Üniversitesi BYYO’ları adını almışlardır.

\section{Illetișim alanında eğitici eğitimine yöneliș}

İstanbul Üniversitesi Gazetecilik Enstitüsü'nde derslerin bir kısmı, İktisat Fakültesi öğretim üyelerince verilirken, gazetecilik meslek derslerini çeşitli gazeteciler vermiştir. AÜ SBF BYYO'da ise, programdaki sosyal bilimler derslerini SBF öğretim üyeleri verirken, iletişimle ile ilgili dersler UNESCO ve Fullbright Komisyonu'nca sağlanan uzmanlarca verilmiştir. Bu işin böyle sürdürülmeyeceği anlaşılınca, AÜ SBF BYYO'da verilmesi gerekli olan iletişim dersleri için asistan alınarak öğretim üyesi olarak yetiştirilmesi uygun bulunmuştur.

Alınan asistanların bazılarına UNESCO tarafından burs sağlanarak $A B D^{\prime}$ de ve $B B C^{\prime}$ de eğitim almaları sağlanmıştır. Ayrıca, yine alınan asistanlar, SBF doktora programlarına yönlendirilmişlerdir. SBF'deki ilk iletişim doktoraları 1970'li yıllar içinde tamamlanmıştır. "İlk Beşler" adı verilen doktora tezlerini sırasıyla Ünsal Oskay, Oya Tokgöz, Aysel Aziz, Uygur Kocabaşoğlu ve Nilgün Abisel hazırlamışlardır. 
AÜ SBF' de tamamlanan doktora tezleri dışında iletişim alanında eğitici yetiştirilmesi yönünden farklı eğitim programları izlenmiştir. Bunları sırasıyla aşağıdaki şekilde özetlemek mümkündür.

1. Hukuk fakültelerinde 1960 'lı yılların sonunda tamamlanan doktora tezleri

2. Eskişehir İktisadi ve Ticari İlimler Akademisi'nde tamamlanan doktora tezleri

3. Yurtdışında Milli Eğitim Bakanlığı'nca sağlanan burslarla tamamlanan doktora tezleri

4. 1982 yılında Yüksek Öğretim Kurumu Yasası gereğince açılan lisansüstü programlarda tamamlanan doktora tezleri

\section{AÜ SBF ile hukuk fakültelerinde tamamlanan doktora tezleri hangi koșullar altında hazırlandı?}

Türkiye' de iletişim eğitimi bir yandan ilerlerken, iletişim eğitimini sürdürecek eğiticilerin yetiştirilmesinde AÜ SBF'nin oynadığı rol gerçekten çok önemlidir. Hukuk Fakültesi/leri ise basın ve iletişim hukuku alanında doktora vererek, basın ve iletişim hukuku alanında eğiticilerin yetişmesine katkı sağlamışlardır. Üzerinde önemle durulması gereken tezler ise, Hukuk Fakültelerinde 1960'l1 yılların sonu itibariyle yapılan doktora tezleri ve AÜ SBF'de 1970'li yıllar içinde verilmiş bulunan kitle iletişim araçları, radyo, televizyon, sinema üzerine yapılmış bulunan doktora tezleridir.

Hukuk Fakültelerinde tamamlanan iki tez, hiç kuşkusuz, Siyasal Bilgiler Fakültesinde tamamlanan doktora tezlerine hukuki alt yapı ve katkı sağlamıştır. Vurgulanması gereken ise, yedi doktora tezinin seçtikleri konuları itibariyle, Türkiye'de kitle iletişim araçlarını üzerinde konuşulur, fikir yürütülebilir, tartışılabilir hale getirmiş olmalarıdır. Hiç kuşkusuz bu nokta gerçekten çok önemlidir çünkü kitle iletişim araçları öne çıkarılarak, bu araçların medya-siyaset ilişkileri açısından rolleri ve önemlerine vurgu yapılmıştır.

Üzerinde durulacak olan yedi doktora tezi hangi koşullar altında neden ve niçin hazırlanmışlardır? Nasıl bir ortam içinde tezlerin konuları seçilmiştir? Tezleri yazanlar yazarken ne gibi zorluklarla karşı karşıya gelmişlerdir? Bu zorlukları aşmayı başarabilmişler midir? Bu sorulara yanıt bulabilmek pek kolay değildir, hatta çetrefillidir. Bu noktada ise, tezlerin yapıldı̆̆ı, yazıldı̆̆ı 
ve savunulduğu koşulları ve işledikleri konuları dikkatli bir biçimde irdelemek ve değerlendirmeyi gerektirmektedir.

1960 sonrası Türkiye' sinde hem planlı ekonomiye geçilmiş hem de yeni kurulan TRT kurumu üzerinde fazlasıyla durulmaya başlanılmıştır. Planlı bir ekonomi, beş yıllık planlarla düzenlenirken, planlar hem ekonomik hem de sosyal planlamaya yer vermişlerdir. Yapılan ilk planlarda ülkede mevcut toplumsal ve ekonomik koşullar dikkate alınarak, nasıl bir toplumsal kalkınma ve gelişme sağlanabileceği, nelerin ülkede yapılabileceği üzerinde ayrıntılı olarak durulmaya çalışılmıştır.

İlk iki beş yıllık kalkınma planında, Türkiye'de mevcut bulunan radyoların teknolojisinin nasıl geliştirileceği ve radyonun nasıl ülke içinde yaygınlaştırılacağı üzerinde ayrıntılı olarak durulurken, ülke arazisinin engebeli olması nedeniyle ise, televizyon yayınlarının o yıllar itibariyle başlaması istenmemiştir. Üçüncü beş yıllık planla birlikte televizyon bakımından durumun değiştiğini söylemek gerekmektedir. Bu durumun ise çeşitli nedenleri bulunmaktadır. Ülke içinde yapılmakta olan radyo-link sistemleri tamamlanmakta olduğu gibi, 1968 yılında Federal Alman Hükümeti Türk Hükümetine televizyon yayınının başlatılabilmesi bakımından siyah beyaz yayın yapabilecek bir televizyon vericisi vermiştir.

31 Ocak 1968'de televizyon yayınları Ankara'da haftada üç yayın yapacak şekilde başlatılmıştır. 1970 yılında da radyo-link sistemlerinin tamamlanmasıyla birlikte, tek kanaldan yapılan televizyon yayınlarının ülke düzeyine yayılmasına yönelinmiştir. Hiç kuşkusuz, tek kanallı televizyon yayınını alabilmek için halk televizyon alıcısı almaya başlamış, alamayanlar ise televizyon vericisi bulunan komşusunda televizyon izleme yolunu tutmuştur.

Yeni bir kitle iletişim aracı olan televizyona merak ve ilginin büyük olması, ülkede yaygınlaşırken, paylaşarak, yardımlaşarak, komşuda televizyon izleme anlamına gelen "telesafirlik" olgusunu ve yaklaşımını da beraberinde getirmiştir. Televizyon ülkenin bazı yerlerinde fazla benimsenmemiş ve izlenmemiştir.

TRT’nin 1964 yılında özerk bir kamu kuruluşu olarak kurulması, özerkliğin anlamının ne olduğunun bilinmemesi ve anlaşılamaması nedeniyle çok yadırganmıştır. Hele hele televizyon yayınının başlaması, işleri daha da kızıştırmıştır. Halk radyoyu az çok bilmekte, yayınlarını izlemektedir. Ama radyo devlet tarafından kurulmakta, işletilmekte ve denetlenmektedir. Televizyon 
gibi yeni bir kitle iletişim aracı ise, alışık olduğu radyo yanında halk için bambaşka bir dünyadır.

İşte bu noktada olanlar olmuştur. Halk hem şaşırmış, hem de televizyonunun ona ne getireceğini çok merak etmiştir. Radyo programcılığı fazla gelişmemiş olduğundan televizyon yayınlarının başlamasıyla birlikte, yayınlarda kullanılan yabancı yapım programlar halkı şaşkına çevirmiştir. Bir yandan halk yabancı yapım programları tartışırken, diğer yandan ise içeriğini eleştirmeye başlamışlardır. Bu noktada ise politikacılar devreye girmiştir. Televizyonu, medya ve siyaset açısından tartışmaya yönelmişlerdir.

Asıl önemlisi ise birdenbire halkın gündemine düşen özerklik ve tarafsızlıktır. BBC modeline uygun olarak kurulan TRT'nin yasasında yer alan özerklik ve tarafsızlık kavramlarına halk hiç alışık olmadığı gibi, bu kavramları bilmediği için önce çok yadırgamış, sonra da tartışmaya yönelmiştir. Bu kavramları anlayan ve anlamayanlar devamlı olarak "özerklik, tarafsızlık ne demek ola ki?" şeklinde tartışmalarını sürdürmüşlerdir. Kafaları ise bu kavramlara pek yatmamıştır. Politikacılar da bu işin içinde yer alarak, TRT'nin özellikle yaptığı televizyon yayınlarını ve verdiği haberleri kıyasıya eleştirmişlerdir. İşi daha da kızıştırmışlardır.

1960'lı yıllarda tamamlanmış bulunan ve inceleme konumuza dahil ettiğimiz iki iletişim hukuku tezinin konularının özerklik ve özgürlükler bakımından seçilmesi ise, hiç kuşkusuz, günün koşulları itibariyle çok tutarlıdır. Hukuk tezi olarak hazırlanan iki tezde araştırmacılar, radyo bakımından özerklik ve özgürlük kavramlarının üzerinde durarak, bu kavramların yasal olarak ne anlama geldiğini anlatmak ve değerlendirmek istemişlerdir. Aslında yapmak istedikleri arasında, 1964'ten itibaren TRT'nin, kuruluşuyla birlikte, özerklik, tarafsızlık ve özgürlük açısından konumunun ne olduğuna işaret etmek de bulunmaktadır.

12 Mart 1971 askeri darbesinden ve 1961 Anayasasında ve 359 Sayılı TRT Yasasında yapılan değişiklikten sonra, 1970'li yıllarda AÜ SBF' de yapılan doktora tezleri ise, özellikle kitle iletişim araçları olan radyo, televizyon, sinema üzerinde odaklanmışlardır. Hukuk açısından radyoya bakma yerine, radyo, televizyon, sinema üzerinde durma $S B F^{\prime}$ de yapılan doktora tezlerinin ana bakış açısını oluşturmakla kalmamıştır, bu tezler aynı zamanda günün toplumsal koşullarına uygun olarak hazırlanmışlardır. Ayrıca, bu tezler AÜ SBF BYYO'dan asistanlarca hazırlanmış olduğu için, BYYO'nun yapmakta olduğu iletişim eğitimiyle de yakın ilişki içindedir. 
1971'den itibaren, 1972, 1975 ve 1978 yılında bitirilen beş doktora tezini hazırlayan Ünsal Oskay, Oya Tokgöz, Aysel Aziz, Uygur Kocabaşoğlu ve Nilgün Abisel olmuştur. Bu isimler AÜ SBF BYYO'nun ilk asistanlarıdır. İlk dördü SBF mezunudur. Nilgün Abisel ise, BYYO'dan ikinci dönem mezunu olma özelliğini taşımaktadır. Hepsi alanında daha sonraki yıllarda önemli isimler olan doktora sahipleri, Ankara Üniversitesi'nden sonra farklı üniversitelerde hizmet vermişlerdir.

Radyo, televizyon ve sinema üzerinde SBF'de 1970'li ylllar içinde hazırlanan doktora tezleri, iletişim alanında hangi kitle iletişim aracı üzerinde çalışılabileceği bakımından ana çerçeveyi çizmiştir demek yanlış olmaz. Bununla birlikte, gazete, dergi, kitap üzerinde doktora tezinin hazırlanmamış olmasını ise büyük bir eksiklik olarak kabul etmek gerekmektedir.

1970'li yıllar içinde üç önemli kitle iletişim aracının üzerinde doktora tezlerinin hazırlanması önemlidir. Bu durumu o yıllar bakımından bir başlangıç noktası olarak ele almak yanlış olmaz. Üç kitle iletişim aracının 1970'li yıllar içinde yapılan doktora tezleriyle birlikte öneminin vurgulanması ve değerlendirilmesi, aynı zamanda, daha sonraki yıllar içinde yapılacak olan doktora tezlerinin yönünü belirlemiştir. Basın, halkla ilişkiler, reklamcılık, fotoğrafçılık, iletişim kuramı, yeni iletişim teknolojileri ve medya araştırmaları bakımından yapılan araştırmalar için gerekli olan zemini de hazırlamışlardır.

Hiç kuşkusuz, 1960'lı yıllarda TRT'nin özerkliği üzerinde başlayan çeşitli kavramsal ve hukuksal tartısmalar, iletişim alanına yön ve şekil kazandırmıştır. Yapılan bu tartışmaların, kitle iletişim araçlarının araştıılmasının gerektiğini vurgulamaları, bu araçların toplum içinde rolünün ve öneminin anlaşılmasını da beraberinde getirmiştir. Türkiye' de iletişim araştırmalarının yapılması bakımından yeni bir dönem başlarken, bu dönemle birlikte peş peşe pek çok yeni iletişim araştırmasının yapılmasının önünü de açmıştır.

\section{0 'I y ylların sonu itibariyle hazırlanmıș bulunan iletișim hukuku tezi olarak adlandırılabilecek olan iki doktora tezi}

Bu tezlerin ilki Cengiz İ. Taşer tarafından hazırlanmış bulunan, "Radyonun Organizasyonu ve Özerkliği" başlıklı doktora tezidir. 194 sayfa uzunluğundaki doktora tezi, 1969 yılında TRT Basılı Yayınlar Müdürlüğü tarafından basılmış bulunmaktadır. Bununla birlikte, tezin Türkiye'de o yıllar itibariyle mevcut bulunan hangi hukuk fakültesinde, hangi tarihte savunulduğu hakkında bilgiler elimizde mevcut değildir. 
Cengiz Taşer yapmış olduğu çalışmada radyonun organizasyonu ve özerkliği üzerinde dursa bile, bu duruşunun yalnız radyoyla ilgili olmayacağını, 1961 Anayasasının ve 359 sayılı TRT Yasasının ilgili hükümleri bakımından televizyonu da kapsayacağını çalışmasında belirtmektedir.

Bu konuda yapılmış bulunan ikinci tez Ersan İlal'a ait bulunmaktadır. "Radyo Hürriyeti ve Özerklik ve 1961 Anayasası" başlıklı doktora tezi, 1972 yılında basılmıştır. Ersan İlal'ın doktora tezinde Cengiz İ. Taşer'in çalışmasından yapılmış pek çok alıntı ve bu teze yapılmış olan çeşitli atıflar yer almaktadır. Cengiz Taşer'in tezinin, Ersan İlal'in tezinden önce yapılmış ve savunulmuş olduğu, bu şekilde daha çok kesinlik kazanmaktadır denilebilir.

Her iki çalışmanın vurgulanması gereken en önemli özellikleri ise, 1961 Anayasası ve 359 sayılı TRT yasasının hükümlerini dikkate alarak hazırlanmış çalışmalar olmalarıdır. 12 Mart 1971 askeri darbesinden sonra, gerek 1961 Anayasasında gerekse 359 sayılı TRT yasasında yapılmış olan değişiklikleri iki çalışma da dikkate almamıştır. Bu çalışmalar için asıl önemli olan özerk bir kamu kuruluşu olarak kurulan TRT'nin kurulmasıyla birlikte başlayan özerklik tartışmalarıdır.

\section{Cengiz ì. Tașer'in yapmıș olduğu çalıșma}

Cengiz Taşer'in hazırlamış bulunduğu çalışma, başlangıç, üç kısım, 12 bölüm ve sonuçtan oluşmaktadır. 194 sayfa uzunluğundadır. Çalışmaya Almanca bir özet de eklenmiştir. Radyonun organizasyonu ve özerklik dişında, radyo organizasyonları olarak dünyada mevcut bulunan organizasyonlara ayrıntılı olarak değindiği gibi, radyo ve televizyonla ilgili çeşitli kavramlar ve teknoloji üzerinde de durmaktadır.

Tekel altında bulunan ve özel teşebbüsçe kurulan ve işletilen çeşitli radyo organizasyonlarından ve yasal düzenlemelerden çeşitli örnekler vermektedir. Devlet tekeli altında işletilen radyolar bakımından Batı Almanya, Fransa, SSCB'yi gösterirken, “atipik devlet tekeli” örneği olarak İngiliz yayın kuruluşu BBC'yi vermektedir. Özel teşebbüsce işletilen radyolar için ABD örneğini göstermektedir.

Türkiye'de radyonun 1964 yılı öncesi durumunu da dikkate alan Cengiz Taşer, Türkiye'de radyonun rejiminin ve mevzuatının kısa bir tarihçesini değerlendirmektedir. Taşer'in çalışmasının ana ekseni 1961 Anayasası ve 359 sayılı TRT yasası üzerinedir. Taşer, özerklik, özgürlük ve organizasyon 
kavramlarını 1961 anayasasının nitelikleri ve 359 sayılı TRT yasasının ilgili hükümleri bakımından tartışmakta, TRT yasası ve uygulamaları bakımından ortaya çıkan çeşitli sorunlara da değinmektedir. Cengiz Taşer'in çalışmasının en önemli bölümünü ise çalışmasından çıkarmış olduğu sonuçlar oluşturmaktadır. Çalışmasının 187-191. sayfalarında yer alan sonuçlarda üzerinde durdukları bir hayli ilginçtir.

Çalışmasında “TRT’nin özerk bir kamu kurumu olduğunu” savunduğunu belirten Cengiz Taşer, “Özerk kamu kurumu niteliğindeki radyo yeterli şartlara rağmen, siyasi partiler veya siyasi akımlardan bir veya birkaçına angaje olması ihtimal dışı değildir. Bu sorun bu noktada gerçekten son derecede dikkat edilmesi gerekli bir dar geçit oluşturmaktadır" şeklinde bir sonuca ulaşmaktadır. Bu sonuç, 1971'den sonra getirilen değişikliklerle birlikte, TRT'de gerçekten yaşanacak çok önemli siyasal nitelikli sorunlara işaret eder niteliktedir.

“Olayları, objektif olarak tespit etmek ve yaymak, yorumlarında tarafsız olmak, özerk radyonun varlık şartıdır", "TRT Kurumunun tarafsızlığını yorumlarken Atatürk devrimleri, çağdaş uygarlık hedefi ve laiklik prensibi söz konusu olunca, bu devrimler, hedef ve prensiplerden yana taraflıdır" şeklindeki diğer bir sonucunda ise Taşer, tarafsızlık ve sınırlarına da değinmeden edemediğini göstermektedir.

Ayrıca, bir diğer sonucunda da özerklik üzerinde durmaktadır: “Özerklik, program yapmada özerklik, yönetimde özerklik, mali özerkliği içine alan bir bütündür. Radyo yayın kurumunun 'özerk' olması demek, bu üç alanda 'özerk' olması anlamına gelir."

“Devlet tarafsız yayın yapacak radyo kuruluşunun var olmasını sağlayacak şartları - serbestçe haber alabilmesi/verebilmesi veya radyonun programlarını serbestçe yapabilmesi, kişilerin herhangi bir engelle karşılaşmaksızın, radyoları dinleyerek bir kanaat sahibi olmaları ve kamu oyunu böyle bir ortam içinde oluşturmayı hazırlamak görevindedir. Bu şartları devlet sağlamak zorundadır" şeklinde çıkardığı başka bir sonucunda ise devletin radyo bakımından üstlenmesi gereken görevleri açık ve seçik sıralamaktadır. Cengiz Taşer'in çalışmasının son sonucu gerçekten çok önemli bir noktaya parmak basmaktadır.

"Siyasi iktidarın emrinde ve onun sözcüsü durumunda olmayan bir kamu kurumu niteliğinde organize edilmiş radyoculuğun yurdumuzda eski 
bir mazisi yoktur. Bu yeni düzenin bazı çevreleri, bazı kişileri, bazı güçleri rahatsız etmesi pekala mümkündür. İşte özerkliğin değeri bu rahatsızlıkla iyi anlaşılabilir ve açıklanabilir" diyerek Taşer özerkliği tanımlamaya çalışmakta ve devam etmektedir:

Burada en büyük görev özerk radyonun kendisine aittir. Bu görev özerkliğin nedenini, amacını iyi anlamak, iyi değerlendirmek ve bu özerkliğe sahip çımaktır. Aksi halde özel mevzuat değişikliğine de lüzum kalmaksızın, özerkliğin küçük menfaatler karşılığında değiştirildiği veya kişiliksiz yönetimler elinde kaybolup gittiğini görmek gibi bir acı sonuca katlanmak gerekir.

Bu sonucunda daha önceki sonuçlarının bazılarını kısmen yinelemekle birlikte, sanki uzağı görüyormuş gibi, 1971'den sonra hem 1961 Anayasası hem de 359 sayılı TRT yasasında yapılan değişikliklere işaret ediyor gibidir. Özerk TRT'nin kuruluşuyla birlikte toplum içinde görülen rahatsızlıklara da değinerek, olabilecekler üzerinde durmuştur. Gerçekten 1964'te bir özerk kamu kuruluşu olarak kurulan TRT, 1961 Anayasasının ilgili maddeleri ve 359 sayılı TRT Yasasıyla 1971 yılına kadar ancak yedi yıl yönetilebilmiştir.

1971'de Anayasa ve 359 sayılı TRT yasasında yapılan değişiklikle birlikte, TRT özerk bir kamu kuruluşu olmaktan çıkmış, tarafsız yayın yapan bir kamu kurumu şekline dönüştürülmüştür. Cengiz İ. Taşer ise, nasıl bir rastlantıdır ki, tarafsız yayın yapan bir kamu kurumu olan TRT'de 1978-1979 yılları arasında genel müdürlük görevinde bulunmuştur. 1979 yılında Taşer görevden alınarak Doğan Kasaroğlu genel müdür yapılmıştır.

Cengiz Taşer'in yaptığı çalışmanın, TRT’nin özerk bir kamu kuruluşu olarak özerkliğini savunan bir çalışma olması nedeniyle tarihsel açıdan önemi ve rolü olduğunu söylemek hiç de yanlış olmaz. İletişim hukuku açısından ise önemini ve değerini yadsımamak gerekmektedir. Türk iletişim literatüründe ise çalışması bir iletişim hukuku araştırması olarak tarihi yerini çoktan almıştır.

\section{Ersan illal'ın yapmıș olduğu doktora çalıșması (1969)}

Ersan İlal'in hazırlamış bulunduğu "Radyo Hürriyeti, Özerlik ve 1961 Anayasası" başlığını taşıyan doktora tezi 1970 tarihinde İstanbul Hukuk Fakültesi'nde savunulmuştur. 113 sayfa uzunluğunda bulunan tezin yayınlanması ancak 1972 yılında gerçekleşebilmiştir. Cengiz Taşer'in çalışmasından sonra, Ersan İlal'in yaptığı çalışma radyo hürriyetinden başlayarak özerkliği savunan bir çalışma özelliğini taşımaktadır. Özerklik bakımından 1961 Anayasası gerekçelerinden başlayarak, ön tasarılara da değinmektedir. 
1961 Anayasasının ilgili hükümlerini inceledikten sonra, 359 sayılı TRT yasasının özerklikle ilgili hükümleri üzerinde durmaktadır.

Radyo rejimleri ve organizasyonları bakımından İlal'in verdiği örnekler Cengiz Taşer'le benzerlik taşımaktadır. Her iki çalışmada da, TRT'nin yapısı üzerinde ayrıntılı olarak durulduğu görülmektedir. Yayınlarda özerkliğe, mali ve teknik özerkliğe, denetimlere çalışmalarda yer verilmektedir. Daha önce de belirtildiği gibi, Ersan İlal'in tezinde Cengiz Taşer'den yaptığı alıntılar ve atıflar dikkate alındığında, bu çalışmadan İlal'in yararlanmış olduğunu söylemek yanlış olmamaktadır. Bununla birlikte İlal' in yaptığı çalışmanın Taşer'in çalışmasından ayrıldığı noktaların da bulunduğunu söylemek gerekir.

Giriş, iki bölüm ve özetten oluşan İlal'in tezine İngilizce bir özet eklenmiş olduğu görülmektedir. Radyo hürriyeti adı altında başlayan çalışmada radyo alanındaki teknik gelişmeye değinildikten sonra, ifade hürriyeti üzerinde durulmaktadır. İfade hürriyetinden sonra kitle haberleşme araçları ve haberleşme hürriyetine geçilmektedir. Çeşitli ülkelerde ilgili mevzuat ve radyo hürriyetine de yer verilmektedir. Hâlbuki Taşer çalışmasında ifade hürriyetini kullanmamakta, düşünceleri açıklama, haber alma ve verme ile radyo özgürlüğünden söz etmektedir. Aslında, dikkatle incelendiğinde her ikisinde kullanılan terminoloji farklıymış gibi görünmekle birlikte aynı noktada birleşmektedirler.

Ersan İlal'in tezinde, 1961 Anayasası ve özerk radyoyu değerlendirirken, 1961 anayasası ön tasarısı ve gerekçesi üzerinde de durduğunu söylemek gerekir. Özellikle, 1961 Anayasasının 121. maddesinin gerekçesini çok dikkatle değerlendirmiştir. DP'nin 1960 öncesi devlet radyosunu partizanca propaganda aracı olarak kullanmasının, 1961 Anayasasındaki özerk radyo düzenlemesinin hazırlayıcısı olduğuna işaret eden İlal, bu durumun 1961 Anayasasının 121. maddesine aynen yansıdığını söylemektedir.

Ersan İlal'ın çalışmasının belki en canlı alıcı noktası özel radyo istasyonları kurulması ve radyo hürriyeti üzerinde durmuş ve kendine göre yeni bir görüş ortaya atmış olmasıdır. “Özerklik, tekel ve kamu tüzel kişiliği ayrı kavramlardır. Özerklik zorunlu olarak kamu tüzel kişiliği ve tekeli kendiliğinden gerektirmez" diyen İlal, özerkliği ön gören 1961 Anayasasının 121. maddesinin tekel ve kamu tüzel kişiliğini zorunlu kıldığını belirtmektedir. Bununla birlikte, İlal, bu konunun tartışılmasını da istemektedir:

Özel radyo istasyonları ve radyoda ifade hürriyeti kavramları, 1961 Anayasası yapılmadan önce üzerinde durulmamış kavramlardır. Oysa 1961 Anayasasının 
20. ve 26. maddeleri genellikle kamu tüzel kişileri elindeki haberleşme araçları ayrımı yaparak, radyo ifade hürriyetini düzenlemekte, 40. maddesiyle de özel teşebbüs hürriyeti hakkında hükümler getirmektedir (İlal 1972, s.88).

Bu noktada ise, İlal'in söyledikleri üzerinde durmak anlamlı olmaktadır. "Daha önceki anayasa düzeninde bulunmayan bu açık hükümler karş1sında devlet radyosundan ayrı özel radyo kurma hakkında söz edilebileceği kanısındayız" diyen İlal bu duruma örnek olarak özel yüksek eğitim kurulabilmesinin mümkün olabilirliği üzerinden vermektedir. "Aynı ayrımın, radyo hizmeti için de yapılabilmesi gerekmektedir."

Bu görüşünü tamamlamak bakımından Ersan İlal'ın bazı eklemeler yaptığı da görülmektedir. “Örneğin bu muhteva ayrımını burada da yapmak, yalnızca müzik veya reklam yayını yapan özel radyoların 121. madde dışında kalacağını iddia etmek mümkün gibi görünmektedir." Bu bakımdan ise İlal, bazı hukukçuların görüşlerine yer vermeyi de ihmal etmemektedir.

Bu konuda ise Ersan İlal, "anayasanın düzenlemesinin yetersiz ve çelişik bulunduğunu kabul etmek gerekmektedir" şeklinde görüş bildirmektedir: "Özerlik bir hizmetin görülmesinde kamu yararını hem siyasi iktidarın hem de özel çıkarlar ve bunların iktisadi iktidarı karşısında koruyan bir araçtır."

İlal, “özerkliğin iki yönlü niteliğinin 121. maddenin yorumlanmasında göz önünde tutulması gerektiğini" de ileri sürmeyi uygun görmektedir. Anayasa Mahkemesinin son yıllarda Türkiye'de ortaya atılan görüşlere uygun olarak bu görüşlere katıldığını ekleyen İlal, “ancak özel radyo istasyonlarına anayasanın izin verdiği kabul edilse bile, kanımızca bu istasyonların özerk olarak düzenlenmesi gerekmektedir" şeklindeki görüşünü Alman Anayasasının bir kararı ile tamamlamaktadır.

"Radyo hürriyeti teminat altındadır hükmüne dayanarak özerklik gereklidir. Özerlik kamu tüzel kişiliğini zorunlu kılmaz". İlal bu noktada, "Bizde de Anayasanın 20. maddesine uygun olarak, böyle sonuca varılması gerekmektedir." şeklinde son sözünü söylemektedir (1972, s.88).

İlal'ın çalışmasının sonuç bölümünde çalışmasından iki sonuç çıkardığı görülmektedir:

1. 1961 Anayasasının kamu tüzel kişiliği hakkında getirdiği hükümlerde kesinlik yoktur ve açık bir tekel hükmü getirilmemiştir.

2. 359 sayılı kanunda bir tekel hükmüyle birlikte özel hukuk kuru- 
luşlarına yön veren hükümler de bulunmamaktadır. Her ne kadar Federal Alman Anayasa Mahkemesinin yorumuna uygun olarak, özel radyoların da özerk olarak düzenlenmesi gerektiği ve radyoda özerkliğin 1961 Anayasasının 121. ve hatta 26. maddelerinin dışında, yalnıza 20. madde hükmü gereği olarak savunulabilse de, organik bir düzenleme için yeterli anayasa teminatı bulunmaması, burada da özerkliği şüpheli kılacaktır.

Sonradan özetlemek gerekirse diye İlal eklemektedir: "1961 Anayasasında özerkliği siyasi iktidar ve özel çıkarlar karşısında koruyacak yeterli teminat hükmü bulunmamaktadır. Oysa uygulama ve olaylar, ülkemizin şartlarının kuruluş ve işleyişte, idari, mali ve teknik özerkliği teminat altına alacak değişiklikleri gerektirmektedir."

Ersan İlal'ın vurgulamak istediği ise, özel radyoların kurulabilmesinin Anayasa ve 359 sayılı yasada yapılacak değişikliklerle mümkün olabileceğidir. Bu noktadaki görüşleri aynı yıllar içinde çeşitli gazete makalelerine yansısa bile, ancak 1982 Anayasasının 133. maddesinde 1993'te yapılan değişiklikle birlikte yaşama geçebilmiştir. 1990'lı yıllarda özel teşebbüs tarafından kurulan radyo ve televizyon istasyonları yasal hale gelmiştir. Genel anlamda RTÜK Yasası olarak bilinen yasayla da radyo ve televizyonlar meşruiyet kazanmışlardır.

\section{0'li yıllarda AÜ Siyasal Bilgiler Fakültesinde hazırlanan doktora tezleri: ilk beșler}

\section{Ünsal Oskay'ın yapmıș olduğu çalıșma (1971)}

1970'li yıllarda AÜ SBF'de yapılan ilk iletişim doktora tezinin Ünsal Oskay tarafından yapılmış olduğu hep kabul görmüş̧ür. Aslında, Ünsal Oskay'ın "Toplumsal Gelişmede Radyo ve Televizyon: Geri Kalmışlık ve Televizyon" adını taşıyan çalışması, Oskay'ın "TRT Bilimsel Araştırma Büyük Ödülü" ile onurlandırılmış bulunan bir çalışmasıdır. Çalışma, 1971 yılında SBF yayınları arasında yayınlanmıştır.

Ünsal Oskay'ın doktora tezi ise, "Gelişim Açısından Kültür Değişimi" başlığını taşıyan çalışmadır. Teze SBF Kütüphanesinde bulunan doktora tezleri arasında ulaşılamamıştır. Bu çalışmasının, TRT Bilimsel Ödülünü kazanan çalışmasından önce hazırlanmış olması olasıdır. 
Ünsal Oskay'ın "Toplumsal Gelişmede Radyo ve Televizyon” adını taşıyan çalışması 118 sayfa uzunluğundadır. Giriş, 4 bölüm ve sonuçtan oluşan çalışmanın ekleri arasında bazı haritaların yer aldığı görülmektedir. Tezin çeşitli belgeler incelenerek ve kitle iletişim kuramları bakımından çeşitli görüşler değerlendirilerek hazırlanmış olduğunu söylemek gerekmektedir.

Çalışmada, az gelişmişlik açısından ekonomik ve toplumsal gelişmede Türkiye ve dünyada radyo ve televizyon üzerinde durularak, I. bölümde Türkiye'de ve dünyada radyo ve televizyon yayıncılığının gelişimi anlatılmaktadır. II. bölümde üzerinde durulan ise, Türkiye'de radyo ve televizyondan yararlanma olmaktadır. III. bölümde, “Türkiye'deki Uygulamalar ve Değerlendirme" üzerinde durularak, çeşitli raporlarda yer alan görüşlere değinilmektedir. Ayrıca, bu bakımdan, Türkiye' de TRT öncesi ve TRT'nin kurulmasından sonraki uygulamalar da gözden geçirilmektedir.

Aslında Oskay, çalışmasının ilk üç bölümünde yaptığı değerlendirmelerle, Türkiye'de radyo ve televizyonun konumu ve yeri bakımından durum belirlemesi yapmak istemiştir. Çalışmanın IV. bölümünde ise Türkiye'de durum belirlemesi yaptıktan sonra, kitle iletişim kuramları bakımından neler söylenebileceğini tartışmaya açmıştır. Bu yönden de, Ünsal Oskay'ın kitle iletişim kuramları bakımından üç temel kuramsal yaklaşım üzerinde durduğu görülmektedir.

Oskay'ın kullandığı birinci kuramsal yaklaşım kitle haberleşme araçlarının "yapabildikleri" bakımından olurken, ikincisi ise kitle haberleşme araçlarının "yapamadıklarını” değerlendirmek olmaktadır. Kullandığı üçüncü kuramsal yaklaşımda Oskay, "toplumsal gelişmeye yönelebilmiş bir toplumda radyo ve televizyonun değişimci etkinliğini arttırma" üzerinde durmaktadır. Oskay kullandığı kuramsal yaklaşımlarda, daha çok modernleşme ile yeniliklerin yayılması kuramlarını tartışmayı ve değerlendirmeyi uygun görmektedir.

Oskay'ın çalışmasının sonuç bölümünde ise, yapmış olduğu bazı saptamalar da yer almaktadir:

1. Diğer az gelişmiş ülkelerde olduğu gibi Türkiye'de radyo ve televizyon yayınlarından ekonomik, sosyal ve kültürel kalkınmada yararlanabilmek bugünkü toplum yapısı içinde ve bugünkü anlayışla radyo ve televizyon yayınlarıyla çok şeyler yapılabileceği zor görünmektedir. 
2. Az gelişmiş ülkelerde toplumsal gelişme alanında hatta eğitim alanında bile radyo ve televizyondan yararlanma konusunda bilimsel bir görüşe varabilmek, ya da tutarlı bir yayın politikası saptayabilmek için, az gelişmiş ülkelerde "gelişmemişlik" ya da "gelişememe" koşullarını doğru değerlendirmek gerekmektedir. Bu durumun, aslında siyasal ve sosyal bir sorun olarak ele alınması çok önemli bir ön koşul teşkil etmektedir.

3. Türkiye'de radyo ve televizyondan ekonomik, sosyal ve kültürel kalkınma alanında yararlanma konusunda ilgilenenlerin ellerindeki bu iki aracın büyüsüne kapılıp, az gelişmiş bir ülke olan Türkiye' de "gelişmişlik" sorununun ekonomik, toplumsal, kültürel ve ülkenin dış ilişkileri alanında önemli kökleri olduğunu gözden kaçırmamaları gerekmektedir.

4. Az gelişmiş bir ülke olan Türkiye'de radyo ve televizyondan ekonomik, toplumsal ve kültürel kalkınmada yararlanma olanağının, ülkede düzensiz, dengesiz ve dışa bağımlayıcı değil, fakat yenileşmek için girişilen değişimin, bu üç alanın bütün bir değişim süreci boyunca bir toplum yapısına yönelmiş "toplumsal gelişme" modelinin izlenmesine bağlı olmasıdır.

5. Böyle bir model, Türkiye'nin Batı'ya bağımlayıcı, taklitçi bir Batılılaşma yerine, tıpkı Mustafa Kemal dönemindeki ilk arayışlar gibi, daha anlamlı ve özlü bir "uygarlaşma" yolunu bulmasını sağlayabilir.

Ünsal Oskay'ın yapmış olduğu saptamaların günümüzde bile geçerliliği bulunmaktadır. Dönemin "toplumsal gelişme" kuramılla uygunluk içinde olan görüşleri yanında Mustafa Kemal döneminde istenilen "muasır medeniyet düzeyine ulaşılmasına" değinmesi önemli ve anlamlıdır.

Bu çalışmasıyla Ünsal Oskay derli toplu bir şekilde modernleşme ve toplumsal gelişme kuramlarını özetleyerek, bu kuramları Türkçe olarak düzenlemiş ve tanıtmıştır. Bu bakımdan, bu çalışmanın Türk iletişim literatürü içinde önemi ve rolü çok büyüktür.

\section{Oya Tokgöz'ün doktora tezi (1972)}

AÜ SBF'de hazırlanan ikinci doktora tezi, Oya Tokgöz'e ait bulunmaktadır. 1970'li yıllarda AÜ SBF BYYO'da hazırlanın bu çalışma radyo ve televizyon sistemleri, medya sistemleri üzerinedir. Kullanılan kuramsal yaklaşımlar, kavramlar ve yapılan analizler itibariyle Türkiye'de yapılmış ilk siyasal iletişim çalışması özelliğini taşımaktadır. 
“Türkiye ve Ortadoğu Ülkelerinde Radyo ve Televizyon Sistemleri: Mukayeseli Bir Araştırma" adını taşıyan bu çalışmada Cengiz İ. Taşer ile Ersan İlal'in de değinmiş olduğu devlet tekeli altında veya özel teşebbüs elinde bulunan radyo ve televizyonu karşılaştırmalı olarak incelemek ve o yıllar itibariyle durum değerlendirmesi yapılmak istenmiştir.

Bu çalışmada Türkiye dışında, İran, Ürdün, Mısır Arap Cumhuriyeti, Irak, Suriye, İsrail ve Lübnan'daki radyo ve televizyon kuruluşlarının yönetim yapıları ile devlet tekeli modeli ile rekabetçi model (özel teşebbüsçe kurulan) tartışmaya açılmaktadır.

Yapılan çalışmanın tamamı 243 sayfa olup, giriş, dört bölüm, dokuz bahis ve sonuçtan oluşmaktadır. İletişim, kitle iletişim araçları ve düzenlenme şekilleri, çalışmanın I. bölümünde değerlendirilirken, aynı zamanda radyo ve televizyon sistemlerinden örnekler verilmektedir. Ayrıca bu bölüm içinde sistem analizine de yer verilerek, devlet/siyasal sistem ayrımından ne anlaşılması gerektiği, serbest iletişim/güdümlü iletişim üzerinde durulmaktadır.

Çalışmanın II. bölümünde ise Türkiye' deki radyo ve televizyon sistemi tartışmaya açılmaktadır. Bu yönden, Türkiye'de radyo ve televizyonun kısa tarihçesi, radyo ve televizyon bakımından mevcut olan düzen, TRT'nin yayın politikası ile 1971'den sonra getirilmiş bulunan değişiklikler üzerinde durulmaktadır. III. bölümde ise Ortadoğu ülkelerindeki radyo ve televizyonun gelişimi üzerinde durulduktan sonra, bu ülkelerden seçilen bazı örnek ülkelerdeki radyo ve televizyon sistemleri incelemeye alınmaktadır.

Sonuç bölümünde ise Oya Tokgöz'ün hazırlamış olduğu araştırmanın bir özeti ile çıkan sonuçlar yer almaktadır:

1. Devlet tekelinin neden ve niçin kurulduğu gerçeği, bu araştırmanın en önemli bulgularından bir tanesidir.

2. Radyo ve televizyonun kullandıkları yayın ilkelerinin devlet tekeli altında tutulan radyo ve televizyonun siyasal sistemlerin otoritesini meşrulaştırmak bakımından kullanıldığı ortaya çıkmaktadır.

3. Radyo ve televizyona ait yayın olanakları, hatta yayın hatları bile devlet mülkiyetindedir.

4. Reklam yayınlarının kullanılması devlet tekeli altında tutulan ve çalıştırılan radyo ve televizyon örgütleri bakımından tuhaf gelmek- 
teyse de, ticari yayınların rekabetçi modelin esası olmasına rağmen tekel modelinde de kullanıldı̆̆ı ortaya çıkmıştır.

5. Devlet tekeli altında radyo ve televizyonun kullanılmasında dinin rolü bulunmaktadır.

Oya Tokgöz'ün ayrıca "bölgesel bir model kurulabilir mi?” üzerinde durduğu görülmektedir. Bu yönden ise şunlara işaret etmektedir: "Ortadoğu Bölgesine has bir radyo ve televizyon sistemi kurma denemesi yapmanın ancak siyasal sistem ile iletişim sistemi arasındaki yakın ilişkiden hareketle olabileceği ortaya çıkmaktadır. Bölgeye has siyasal sistem modeli, bu bakımdan farklılık gösteren bugünkü siyasal sistemler arasından, belki en akla yatan bir şekilde bölgenin stratejik önemi dikkate alınarak kurulabilir. Bu da otoriter yönetime meyyal, askeri yönü ağır basan bir siyasal sistem olarak tasvir edilebilir. Bölgeye has otoriter sistem modelinin ilişki kuracağı iletişim sistemi de siyasal sistem ile iletişim sistemi arasındaki yakın ilişkiden dolayı yönetiminin şekli ve yapısıyla az veya çok bağlantılı olarak çalışmak durumundadır"' (Tokgöz 1972, s.231-233).

Bu modele göre bölgesel siyasal sistem ile iletişim modelinin çalışması bugünkü durumda bölgedeki mevcut koşulların etkisiyle olmaktadır. Bölgede, hukuki güvenlik mekanizmaları gelişir, iyi çalışırsa, anayasa, yasalar ve uygulamaları, yürütme organının görev ve yetkilerini belirleme yolunu tutacaktır. Ayrıca iletişim sistemini işleten araçlar da güvenliğe kavuşacaklardır. Bireylerin de özgürce yaşamaya başlamaları, siyasal sistemin eylemlerini daha yakından izlemelerini, denetlemelerini sağlayacaktır. Bütün bu koşulların işlemesi, bölgeye huzur ve denge getirecek olan barışın sağlanmasına bağlıdır. İletişim sisteminin bağımsız olarak işlemesi, bir yandan hukuki güvenlik mekanizmasının gelişmesine bağlıysa da, asıl bağımsızlığı siyasal sistem ile sosyal yapı arasındaki etki tepki ilişkilerinin düzenli bir şekilde işlemesiyle sağlanabilecektir (Tokgöz 1972, s.233-234).

Oya Tokgöz'ün yapmış olduğu bölgesel model denemesiyle sistem analizi üzerine kaydığını, sistem analiziyle bölgede durum değerlendirilmesi yapmış olduğunu söylemek gerekir.

Ünsal Oskay’la Tokgöz'ün çalışmaları birlikte değerlendirildiklerinde ise, her iki çalışmanın da o yıllar itibariyle Anglo-Amerikan ana akım iletişim kuramlarının Türkiye'ye uyarlanabilirliğinin denemesini yapmaya çalıştıklarını belirtmek hatalı olmaz. 


\section{Aysel Aziz'in yapmıș olduğu doktora çalıșması (1974)}

Aysel Aziz ve ondan sonra SBF'de 1970'li yıllarda yapılmış olan doktora tezlerinde artık tek bir kitle iletişim aracına yönelme olmuş olduğunu söylemek gerekmektedir. Bu yaklaşımla birlikte tek kitle iletişim aracı üzerinde yoğunlaşılarak bu araç bakımından neler söylenebileceğini tartışmak öne çıkmakta, aynı zamanda ele alınan kitle iletişim aracının daha iyi tanıtılması yapılmış olmaktadır. Hiç kuşkusuz, bu yaklaşımın benimsenmesi hem Türk iletişim araştırmaları hem de literatürü için hem bir yenilik ve hem de büyük bir kazanç olmuştur.

Aysel Aziz'in yapmış olduğu “Televizyonun Yetişkin Eğitimindeki Yeri" başlıklı doktora çalışması, , Türkiye' ye yeni girmiş bulunan bir kitle iletişim aracı olan televizyonun yetişkin eğitimindeki yerini araştıran ampirik iletişim araştırması olma özelliğini taşımaktadır. Türk iletişim literatüründe televizyon üzerinde yapılmış ilk araştırmalar arasında yer almaktadır. Araştırma ampirik bir araştırma olarak önemlidir ve dikkat çekici özelliklere sahiptir.

Çalışma, 1973 yılında bir ampirik araştırma olarak sahada uygulanmış, 1974 yılında SBF'de doktora tezi olarak savunulmuş, 1975 yılında da yayınlanmıştır. 264 sayfa uzunluğundaki çalışmada, giriş, beş bölüm ve sonuç yer almaktadır. Çalışmanın I. bölümünde yapılan deneye dayalı araştırmanın amacı, varsayımları üzerinde durulmakta, neden araştırmanın Ankara' da yapıldığı anlatılmaktadır. II. bölüm ise kalkınmakta olan ülkelerde ve Türkiye'de temel sorunlar ve bu sorunlar içerisinde yetişkin eğitimin yerine ayrılmış bulunmaktadır. III. bölümde yetişkin eğitiminde kitle iletişim araçlarından ve televizyondan yararlanma üzerinde durulmaktadır.

Türkiye'de televizyon yayınları ise IV. bölümde incelenmektedir. V. bölümde ise Ankara'da gerçekleştirilen ampirik araştırmadan elde edilen bulgularının değerlendirilmesi yapılmaktadır. VII. bölümde yapılmış bulunan ampirik araştırmanın toplu özeti ve sonucu verilmektedir.

Aysel Aziz'in toplumsal kalkınma kuramını ve yetişkin eğitimini dikkate alarak yapmış olduğu ampirik araştırmasından genel sonuç bir çıkarmıştır: “Televizyon yayınlarının ülkemizdeki yeni ve bu yeniliğinden ötürü birçok eksiklik ve yetersizliği olmasına rağmen, kamu tarafından artan bir ilgi ile karşılanmaktadır. Kişi, eğlence, eğitim, kültür ve hatta haber kaynağını bu araca çevirmiştir" (Aziz 1975, s.238). 
Aysel Aziz ayrıca yapmış olduğu ampirik araştırmasının bulgularına bakarak çeşitli sonuçlar çıkarmıştır:

1. Şimdiki durumda, televizyon yayınlarından yararlananları, daha çok yaşam düzeyi orta ve yüksek olanlar oluşturmaktadır.

2. Düşük yaşam koşullarında bulunanlar televizyon alıcılarının yüksek ücrette oluşu nedeniyle ya hiç yararlanamamakta ya da oldukça sınırlı olarak yararlanabilmektedirler.

3. Televizyon yayınları ülkemizde salt eğlence ya da eğitim ve haber aracı olarak görülmekte, her ikisinin birlikte verildiği hatta verilmesi gerektiği bir araç olarak kabul edilmektedir. Burada sözü edilen eğitim, gerek geniş anlamı ile bilgi genişletici, kültür verici eğitim ile dar anlamda kişinin yaşamında uygulayabileceği beceri ve uğraşının öğretilmesini amaçlayan eğitimdir (Aziz 1975, s.238).

Çalışmada ayrıca araştırma bulgularına göre televizyonun yetişkin eğitiminde etkin bir kitle iletişim aracı olduğu varsayımlarının geçerliliğinin kanıtlandığı belirtilmektedir.

Asıl önemli olan ise, "televizyonda yer alan eğitsel yayınların etkili olabilmesi, ulusal amaç ve erekleri destekleyici katkıda bulunabilmesi için bulguların ve kanıtlanan varsayımların da yardımı ile şu önerilerde bulunmak istiyoruz" demesidir. Bu bakımdan Aysel Aziz araştırmasının sonunda yedi öneri ileri sürmektedir:

1. Televizyon bir eğlence aracı olarak değil, bir eğitim-haber aracı olarak ele alınmalıdır.

2. Eğitici yayınların amacının ne olduğu saptanmalıdır.

3. Öğrenilmesi amaçlanın konunun izleyici grubunun özellikleri ve öğrenme yöntemleri göz önünde bulundurularak izlenmesi gereklidir.

4. Eğitsel yayının hangi izleyici grubuna sesleneceği daha önce gerek televizyondan gerekse diğer iletişim kanalları ile duyurularak, hedef izleyicinin gerek maddi gerekse manevi olarak hazırlanması sağlanmalıdır.

5. Olasılığı bulunduğu durumlarda, eğitsel yayınların yazılı basınla desteklenmesi sağlanmalı, yayından önce bu olanağın bulunduğu izleyiciye duyurulmalıdır. 
6. Büyük projelerin gerçekleştirilmesini amaçlayan, örneğin okumayazma gibi eğitsel yayınlarda pilot proje çalışmaları yapılmalıdır.

7. Gerek yayın sırasında, gerekse yayın sonrası izleyici grupları ile karşılıklı bir iletişim kurulmalıdır (Aziz 1975, s.241-242).

Aysel Aziz'in yapmış olduğu doktora çalışması, Ünsal Oskay ve Oya Tokgöz' içinde yer aldığı Anglo-Amerikan ana akım iletişim kuramını Türkiye'de tanıtma ve Türkiye'ye uygulanabilirliliği üzerinde durma yaklaşımından ayrılmayan bir çalışma özelliğini taşımaktadır. Ampirik çalışma olması ise, diğer iki çalışmadan ayırıcı özelliğidir.

\section{Uygur Kocabașoğlu'nun hazırlamıș bulunduğu doktora tez çalıșması (1978)}

1970'li yıllarda SBF'de savunulan dördünce tez çalışmasını Uygur Kocabaşoğlu hazırlamıştır. "Şirket Telsizinden Devlet Radyosu: TRT Öncesi Dönemde Radyonun Tarihi Gelişimi ve Türk Siyasal Hayatı" başlıklı doktora tezi Temmuz 1978' de SBF'de Uygur Kocabaşoğlu tarafindan savunulmuş bulunmaktadır.

Radyo Tarihi (İletişim Tarihi) araştırması olarak hazırlanmış olan bu çalışma, TRT arşivlerinde bulunabilen belgelere dayanılarak hazırlanmış bir çalışma özelliğini taşımaktadır. 454 sayfa uzunluğundaki çalışma 1980 yılında yayınlanma olanağı bulmuştur. Giriş, iki kesim, dokuz bölüm ve sonuçtan oluşmaktadır.

Çalışmanın birinci kesimi Türk Radyoculuğunun ilk on yılına (19261936), ikinci kesim ise Devlet Radyosuna (1936-1946) ayrılmıştır. Ayrıca ikinci kesim içinde (1946-1960) ve (1960-1964) yılları içindeki radyonun konumunun değerlendirilmeye alındığı da görülebilmektedir. Daha başka deyişle, radyonun Türkiye'ye girişinden TRT kurumu kuruluncaya kadar geçirilmiş dönemler incelenmeye alınmış bulunmaktadır.

I. kesimde Türk radyoculuğunun ilk 10 yılı içinde (1926-1936) özel teşebbüs elinde bulunan radyoların ayrıntılı olarak incelemesi yer almaktadır. II. kesimde ise, devletin radyoyu üstlenmesi değerlendirilmektedir. Kocabaşoğlu tarafından her iki kesim bakımından yapılan değerlendirmelere bakarak şunları söylemek mümkün görünmektedir. Tarihi belgeler ışığında Türk radyoculuğunun gelişimi kronolojik ve ayrıntılı olarak incelenmiş ve değerlendirilmiştir. 
Yapılan çalışmanın sonuçları ise çok ilginçtir. Uygur Kocabaşoğlu'nun 40 yılı kapsayan bir döneme ilişkin belgeler bakımından yapmış olduğu değerlendirmeleri iki küme içinde toplamış olduğu görülmektedir. Her iki küme içinde çıkarmış olduğu sonuçlar yer almaktadır (Kocabaşoğlu 1980, s.421-428).

a. Bir kitle iletişim aracı olarak radyonun nicelik ve nitelik açısından genel görünümü

b. Türk siyasal ve toplumsal hayatında radyonun yeri ve işlevi

Birinci küme bakımından çıkarmış olduğu sonuçlara gelince,

1. Türkiye'de radyonun sağlıklı bir biçimde büyümediği görülmektedir. Radyonun yöneldiği kitle zaman içinde büyüyüp farklılaşmış olduğu halde, radyo yayınları gerek nicelik gerekse nitelik yönünden bu gelişmeye ayak uyduramamıştır (Kocabaşoğlu 1980, s.421422).

2. Radyonun yayın politikası bakımından yazılı kuralların bulunmayışı, örgütsel -yönetsel yetersizliğin bir sonucu olduğu gibi, radyo yayıncılığının kişisel ve siyasal etkilere alabildiğine açık bırakılması gibi bir sonuç doğurmuştur (Kocabaşoğlu 1980, s.422).

3. İncelenen yıllar boyunca gözlenen başka bir olgu ise, radyonun özellikle program personeli yönünden içinde bulunduğu olumsuz koşullardır. Uzmanlaşma ve profesyonelleşme görülmemiştir. Türk müziği çalışmalarının ise daha ciddi bir personel politikasına sahip olması, radyonun bu işi üstlenmek durumunda kalmasına bağlanabilir (Kocabaşoğlu 1980, s.422-423).

4. Vericiler, alıcılar, yapım olanakları v.b yönünden de radyo son derecede geri kalmıştır. Türkiye radyolarında söz programları, 1960’lara gelene değin, metin okumaktan öteye geçememiştir. Bu durumun nedeni bilgisizlik değildir. Programlar açısından gözlenen gerilik, bilmemenin değil, yapamamanın bir sonucudur. Bunun önde gelen nedeni ise, radyo örgütünün yeterince kurumsallaşamaması, radyoda çalışanların uzmanlaşamamasıdır (Kocabaşoğlu 1980, s.423).

Bununla birlikte, Türk radyoculuğunda gerek örgütsel ve yönetsel, gerekse de programcılık açısından iki atılım gözlenebilmektedir. Bunlar sırasıyla, radyonun 1940 yılında Matbuat Umum Müdürlüğüne bağlanması ve 27 Mayıs 1960'dan sonra yaşanan değişikliklerdir. 
1964 yılında TRT örgütleşememiş, uzmanlaşamamış, profesyonelleşmemiş bir radyoculuğu, hem de uzun yılları kapsayan uygulamalar sonucu yerleşmiş bir takım olumsuzluklarla devralmıştır (Kocabaşoğlu 1980, s.423424).

Uygur Kocabaşoğlu'nun ikinci kesim bakımından çıkardığı sonuçlar birinci kesim ile bağlantılıdır demek yanlış olmamaktadır:

1. Nicelik ve nitelik yönünden 40 y1llık süre sonunda radyoculuğun ulaştığı yer, devletin radyodan yeterince etkin bir şekilde yararlanamadığı gerçeğidir.

2. Siyasal iktidarların radyo konusunda genellikle bilinçli oldukları, buna rağmen radyodan etkin bir şekilde yararlanamadıkları görüşünü iki noktada tamamlamak gerekmektedir (Kocabaşoğlu 1980, s.425-426).

a. Radyonun daha etkin kullanılması için zaman zaman girişimler olmuştur.

b. Ancak bu girişimler uzun soluklu ve kalıcı olmamıştır.

c. Radyo önceleri burjuva ve küçük burjuva kesimlerinin gereksinmelerini gidermek durumunda iken, alıcı sayısı artışı ve marjinal dinleyicilerin devreye girmesiyle bunların beklentilerini de dikkate almak durumunda kalmıştır. Bununla birlikte, radyo esas olarak iktidarda bulunan sınıf ve tabakaların istemlerine, zevklerine uygun olarak çalışmıştır.

d. Türkiye'nin diş dünya ile olan ilişkilerinin özellikle Türkiye'nin Batı kapitalizmiyle bütünleşmesi sürecinde radyodan görece daha etkin bir biçimde yararlanılmış olmasıdır.

Kocabaşoğlu'na göre, 1926-1964 yılları arasındaki Türk radyosunun uygulamalarına baktığımızda şöyle bir genelleme yapabiliriz:

a. Türkiye' de resmi ideolojinin temel öğelerinden birisi "sınıfsız, imtiyazsız, kaynaşmış bir kitle" nin varlığını savunmak olmuştur.

b. Mevcut toplum düzeninin somut, toplumsal alternatiflerini kötüleme konusunda da radyonun bir hayli etkili olduğu söylenebilir.

c. Türkiye içinde radyonun ticari çıkarlara hizmet etme biçimleri, Türkiye'deki kapitalizmin özel koşullarına bağlı olmuştur. 
Uygur Kocabaşoğlu'nun çalışması Türk radyoculuğunun tarihi gelişimini derli toplu bir biçimde anlatmıştır. Aynı zamanda kitle iletişim aracı olan radyoyu çeşitli açılardan irdelemiş olan bir çalışma olma özelliğini de taşımaktadır. Çalışması Türk radyoculuğu bakımından tarihi bir belge olmakla kalmayıp, radyoculuğun gelişim sürecini de kronolojik olarak değerlendirmiş bir çalışmadır.

\section{Nilgün Abisel'in sinema üzerine yapmıș olduğu çalıșma (1978)}

SBF'de 1970'li yıllar içinde iletişim tezi olarak yapılmış bulunan beşinci çalışma Nilgün Abisel tarafından hazırlanmış bulunmaktadır. 1978 yılı Temmuz ayında savunulan çalışma "Türk Sinemasının Gelişimine Genel Bir Bakış" adını taşımaktadır. Giriş, 3 bölüm ve sonuçtan oluşan çalışma 186 sayfa uzunluğundadır. Tez yayınlanmadığı için, teze SBF Kütüphanesinin doktora tezleri arasından ulaşılabilmiştir.

Nilgün Abisel yapmış olduğu doktora çalışmasının giriş bölümünde Türk sinemasının yapısına ve işleyişine dair bilgilerin çok az derlendiğinin üzerinde durarak, sürekli veri ve malzemenin sağlanmasında zorluklar bulunduğuna işaret etmektedir. Konunun seçilmesinin yadırganması nedeniyle, yaptığı çalışma için gözlemlerle bilgi toplanıldığını, kendisine daha çok Yeşilçam'daki sinema çalışanlarının destek verdiğini ifade etmekte ve eklemektedir:

Türk sinema endüstrisinde ham madde üretimine geçilemediği gibi, karmaşık teknolojik sistemler gerektiren aygıtların üretimi de kuşkusuz ülkemizde yapılamamaktadır. Bu eksik yön ilk günden bu yana sinemamızın ana sorunlarını hazırlamıştır. Türk sinema dünya sineması içinde kendine özgü bir yer sağlayabilecek ve gelişen uluslararası film alışverişinden pay alabilecek denli yetkin ürünler verememektedir. Türk sineması uzun süre kolay kar getiren maceracı bir meslek olmaktan öteye gidememiştir (Abisel, 1978).

Nilgün Abisel çalışmasının II. bölümünde Türk sinema sisteminin işleyişini anlatmaktadır. Bu yönden film yapımı, film yapımcısı, film yapma fikri, mali olanaklar, ham madde, yapım işlemleri, yapım maliyetleri, filmlerin pazarlanması, dağıtım sistemi, işletmeciler, seyirci ile yabancı filmlerin Türk sinemasına etkisini tartışmaya almaktadır. Çalışmanın III. bölümünde Nilgün Abisel Türk Sinemasına ilişkin yasal düzenlemeleri değerlendirmektedir.

Asıl önemli olan ise Abisel'in çalışmasının sonuç bölümünde söylemiş olduklarıdır denilebilir: 
1. Sinema alanının bugünkü durumuna ilişkin olan nokta, kapitalist ekonomik sistemin geçerli olduğu ülkemizde, bazı sektörlerde bu sistemin kurallarının daha çok işlerlik kazanmasına karşın, sinemanın bu konuda da diğer sektörlere göre geride kalmış olmasıdır (Abisel 1978, s.183).

2. Türkiye'de yerli film yapımına girişmek ve sürdürmek, olumsuz bu durumda, elindeki çok az sermayeyi kaybetmekten büyük zarar görmeyecek olan, maliyeti alabildiğince düşük tutarak kar elde etmeye çalışan serüven meraklısı girişimcilere kalmıştır. Yabancı film ithalatı bugün de yerli yapımlara oranla daha karlı bir girişim niteliğini korumaktadır (Abisel 1978, s.184).

3. Siyasal iktidarlar, Türk sinemasının verdiği ürünlerin evrensel standartlarının uygunluğu konusunda herhangi bir yönlendirmeye gitmemiş ancak filmlerin içeriğinin egemen sınıfların konumunu tehlikeye sokup sokmaması açısından denetlemeyi uygun bulmuştur (Abisel 1978, s.185).

4. Önemli ölçüde yatırım sermayesi gerektiren sinema endüstrisinin Türkiye'de gösterdiği bir başka farklılık da, hammaddesinin ve aygıtlarının tümüyle yurtdışından ithal edilmesidir (Abisel 1978, s.185).

5. Türk sinemasında yıllar boyu duyulan gereksinmelerin kural dışı yollardan sağlanması, temelinde yine girişimci sermayesizliği yatan, üretim, dağıtım, gösterim sürecinin kopukluğu sonucunu doğurmuştur. Türk sinemasında, film yapımı giderlerinin tefeci niteliğindeki işletmeciler tarafından karşılanması özel bir durum yaratmaktadır. Bu da çok değişik bir işletmecilik modelidir. Bu model zaten pek çok açıdan yetersiz yapımcıların ürettiği filmlerin bir de parayı veren tefeci işletmecilerin sinemada belirleyici bir rol oynamalarına yol açmaktadır (Abisel 1978, s.185-186).

6. Kısıtlı parasal olanaklarla ve küçük yatırımlarla işleyen, Türk sinema endüstrisinden önemli ölçüde kaynak kaybı olmamaktadır.

a. Gişe hâsılatlarından denetimsizlik nedeniyle olan kayıp, salon sahipleri ve işletmecilerin yapımcıya gitmesi gereken gelirleri sinema dışına sızdırmasıyla olmaktadır.

b. Nakit para ödeyerek film izleyen seyirciden elde edilen hâsılatın paylaşılmasında senet kullanımı, Türk sinema endüstrisinde bir diğer parasal değer kaybına neden olmaktadır. 
c. Milyonlarca lira, senet kıran faizciler eliyle sinema dışına çıkarılmaktadır.

d. Son yılların ekonomik dar boğazları Türk sinemasını içinden çıkılması çok güç gibi görünen bir duruma itmişse de, çok köklü önlemler alınmadıkça ya da yepyeni bir düzenlemeye gidilmedikçe, getirilecek pek çok çözüm sistemin işleyişini temelde etkilemeyecek gibi görünmektedir (Abisel 1978, s.186).

Nilgün Abisel'in yapmış olduğu çalışma tümden özel sektör elindeki sinemanın durumunu anlattığı için kendisinden önce hazırlanmış olan dört doktora tezinden ayrılmakta olduğunu söylemek gerekir. Bu çalışmasıyla, Türk iletişim araştırmaları açısından çok önemli noktalara parmak basmış bir çalışma hazırlamıştır.

\section{Değerlendirme}

1960'lı yılların sonu itibariyle ve 1970'li yıllar içinde hazırlanmış bulunan 7 çalışma artık Türk iletişim literatürü içinde çoktan yerlerini almış bulunmaktadırlar. Bu araştırmalar bakımından karşılaştırmalı olarak bir değerlendirilme yapıldığında ise, aşağıda sıralananları söylemek mümkün olmaktadır:

1. SBF' de hazırlanan tezler, o yıllar Türkiye'sinde geçerli olan koşullar ve çıkarılmış bulunan yeni yasal düzenlemeler dikkate alınarak ve önemsenerek hazırlanmış bulunan çalışmalar özelliğini taşımaktadırlar. Dönemin ruhunu ve inancını yansıtmak için büyük bir çaba göstermişlerdir.

2. Doktora tezlerini hazırlayanlar büyük zorluklarla karşılaşarak veri ve belge toplamışlardır. Zorluklara göğüs germekten kaçınmamışlardir.

3. Bu çalışmalar bir veya iki kitle iletişim aracını gündemlerine alarak, bu araçların üzerinde fikir yürütülür, konuşulur, tartışılır bir konuma getirmişlerdir.

4. Medya ve siyaset arasındaki yakın ilişki, hazırlanmış bulunan çalışmalara doğrudan veya dolayı olarak yansımış bulunmaktadır.

5. Bu çalışmaların hepsi geçirilen bir akademik eğitim sonucu olarak bir unvan kazanmak yönünden olduğu kadar aynı zamanda, eğitim amacına dönük olarak hazırlanmış bulunan çalışmalar özelliğini taşımaktadirlar. 
6. Cengiz İ. Taşer ve Ersan İlal iletişim hukuku açısından Türk iletişim literatürüne katkıda bulunmuşlardır. Buna karşın Ünsal Oskay, Oya Tokgöz, Aysel Aziz, Uygur Kocabaşoğlu ve Nilgün Abisel daha sonraki yıllarda yapılacak olan iletişim araştırmalarının çerçevesini çizmişler ve yönünü belirlemişlerdir. 


\section{Kaynakça}

ABİSEL, N. (1978) Türk sinemasının gelişimine genel bir bakış. Yayınlanmamış tez (Doktora, Ankara Üniversitesi Siyasal Bilgiler Fakültesi).

AZİ, A. (1975) Televizyonun yetişkin eğitimdeki yeri ve önemi. No:148. Ankara: Türkiye ve Ortadoğu Amme Enstitüsü Yayınları.

İLAL, E. (1972) Radyo hürriyeti, özerklik ve 1961 anayasası. İstanbul: Sulhi Garan Matbaasi.

KOCABAŞOĞLU, U. (1980) Şirket telsizinden devlet radyosuna: TRT öncesi dönemde radyonun tarihi gelişimi ve Türk siyasal hayatı. No:142. Ankara: AÜ SBF Yayınları.

OSKAY, Ü. (1970) Gelişim açısından kültür devrimi. Yayınlanmamış tez (Doktora, Ankara Üniversitesi Siyasal Bilgiler Fakültesi).

OSKAY, Ü. (1971) Toplumsal gelişmede radyo ve televizyon: gelişmişlik açısından olanaklar ve sinırlar. No:2. Ankara: AÜ SBF Yayınları.

TAŞER, İ. C. (1969) Radyonun organizasyonu ve özerkliği (mukayeseli bir anayasa hukuku araştırması). No:5. Ankara: TRT Basılı Yayınlar Müdürlüğü Yayınları.

TOKGÖZ, O. (1972) Türkiye ve Ortadoğu ülkelerinde radyo ve televizyon sistemleri: mukayeseli bir araştırma. Ankara: Sevinç Matbaası.

TOKGÖZ, O. (1985) Siyasal iletişim. ATAUZ, S. (der.) içinde. Türkiye'de sosyal bilim araştırmalarının gelişimi. Türk Sosyal Bilimler Derneği Yayınları, s.97-116.

TOKGÖZ, O. (2000) Türkiye' de iletişim araştırmaları nereden nereye? Kültür ve İletişim, 3(2), s.12-30.

TOKGÖZ, O. (2006) Türkiye' de iletişim araştırmalarında iletişim eğitiminin rolü ve önemi [Çevrimiçi]. http: / / globalmedia-tr.emu.edu.tr.

YALMAN, A. E. (1974) The development of modern Turkey as measured by its press. USA: Columbia University. 